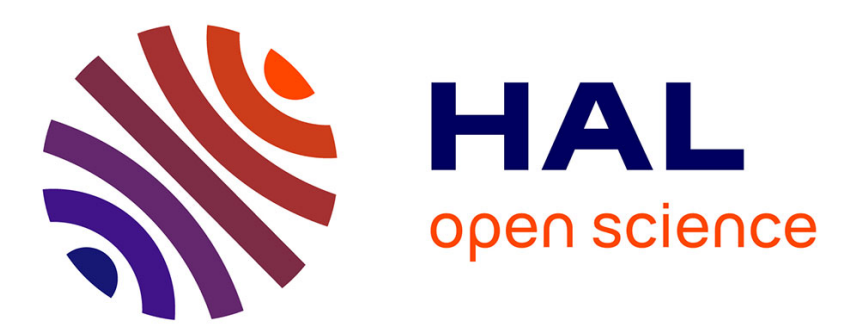

\title{
Characterization of 241Am and 134 Cs bioaccumulation in the king scallop Pecten maximus: investigation via three exposure pathways
}

Marc Metian, Michel Warnau, Jean-Louis Teyssié, Paco Bustamante

\section{- To cite this version:}

Marc Metian, Michel Warnau, Jean-Louis Teyssié, Paco Bustamante. Characterization of 241Am and 134Cs bioaccumulation in the king scallop Pecten maximus: investigation via three exposure pathways. Journal of Environmental Radioactivity, 2011, 102 (6), pp.543-550. 10.1016/j.jenvrad.2011.02.008 . hal-00593369

\section{HAL Id: hal-00593369 \\ https://hal.science/hal-00593369}

Submitted on 14 May 2011

HAL is a multi-disciplinary open access archive for the deposit and dissemination of scientific research documents, whether they are published or not. The documents may come from teaching and research institutions in France or abroad, or from public or private research centers.
L'archive ouverte pluridisciplinaire HAL, est destinée au dépôt et à la diffusion de documents scientifiques de niveau recherche, publiés ou non, émanant des établissements d'enseignement et de recherche français ou étrangers, des laboratoires publics ou privés. 

maximus: investigation via three exposure pathways

3

$4 \quad$ Marc Metian $^{1-2}$, Michel Warnau ${ }^{1}$, Jean-Louis Teyssié $^{1}$, Paco Bustamante ${ }^{2}$

61 International Atomic Energy Agency - Marine Environment Laboratories, 4, Quai 7 Antoine Ier, MC-98000 Principality of Monaco

2 Littoral Environnement et Sociétés (LIENSs), UMR 6250, CNRS-Université de La

9 Rochelle, 2 rue Olympe de Gouges, F-17042 La Rochelle Cedex 01, France

Correspondence to: Prof. Paco Bustamante

LIENSs, UMR 6250, CNRS

Université de La Rochelle,

2 rue Olympe de Gouges,

F-17042 La Rochelle Cedex 01,

France.

Phone : +33 546507625

Fax : +33 546458264 .

E-mail : paco.bustamante@univ-lr.fr

metian@hawaii.edu 
25 In order to understand the bioaccumulation of ${ }^{241} \mathrm{Am}$ and ${ }^{134} \mathrm{Cs}$ in scallops living in sediments, the uptake and depuration kinetics of these two elements were investigated in the king scallop Pecten maximus exposed via seawater, food, or sediment under laboratory conditions. Generally, ${ }^{241} \mathrm{Am}$ accumulation was higher and its retention was stronger than ${ }^{134} \mathrm{Cs}$. This was especially obvious when considering the whole animals exposed through seawater with whole-body concentration factor $\left(\mathrm{CF}_{7 \mathrm{~d}}\right)$ of 62 vs. 1, absorption efficiencies $\left(\mathrm{A}_{\mathrm{ol}}\right)$ of 78 vs. 45

31 for seawater and biological half-lives $\left(\mathrm{T}_{\mathrm{b}^{1 / 21}}\right)$ of $892 \mathrm{~d} v s .22 \mathrm{~d}$ for ${ }^{241} \mathrm{Am}$ and ${ }^{134} \mathrm{Cs}$, respectively. 32 In contrast, following a single feeding with radiolabelled phytoplankton assimilation 33 efficiency (AE) and $\mathrm{T}_{\mathrm{b}^{1 / 2}}$ of ${ }^{134} \mathrm{Cs}$ obtained were higher than those of ${ }^{241} \mathrm{Am}$ (AE: $28 \%$ vs. $\left.20 \% ; \mathrm{T}_{\mathrm{b}^{1 / 21}}: 14 \mathrm{~d} v s .9 \mathrm{~d}\right)$. Among scallop tissues, the shells always contained the higher proportion of the total body burden of ${ }^{241} \mathrm{Am}$ whatever the exposure pathway was. In contrast,

36 the whole soft parts presented the major fraction of whole-body burden of ${ }^{134} \mathrm{Cs}$, which was generally associated with muscular tissues. Our results showed that the two radionuclides have contrasting behaviors in scallops, in relation to their physico-chemical properties.

40 Keywords: bivalve; scallop; radionuclide; bioaccumulation; uptake; depuration 


\section{Introduction}

42 During the last sixty years, human activities have resulted in various degrees of contamination of the world seas and oceans with anthropogenic radionuclides (Frielander et al. 2005). Although this contamination tends to decrease (e.g. Toshimichi et al. 2003), it is still a major concern in coastal areas receiving radioactive inputs mainly from industries, nuclear accidents and fallout from nuclear weapon testing and use. Consequently, monitoring programs were established worldwide to monitor the levels of those radionuclides in the marine environment (Nielsen et al. 2007). Generally, surveys are based on the analysis of seawater, sediments and biological samples (e.g., Fegan et al. 2010). Overall, biomonitoring programs present the advantages 1) to reveal the bioavailability of the considered contaminants and 2) to magnify their levels above the analytical detection limits.

The use of marine organisms for monitoring radionuclide contamination is well established (Valette-Silver and Lauenstein 1995, Burger et al. 2007, Thébault et al. 2008). In order to understand field measurements, the characterization of bioaccumulation parameters and/or the relative importance of the different exposure pathways has been carried out for several radionuclides (Ke et al. 2000, Wang et al. 2000, Baines et al. 2005, Borretzen and Salbu 2009). Beside mussels, other bivalve species are used to a lesser extent in biomonitoring programs among which scallops appear of great interest as they highly accumulate trace elements from their environment (Bryan 1973, Bustamante and Miramand 2005, Metian et al. 2008a, 2009a, Pan and Wang 2008). Scallops have also been reported to efficiently concentrate natural and anthropogenic radionuclides such as ${ }^{241} \mathrm{Am},{ }^{137} \mathrm{Cs},{ }^{210} \mathrm{Po},{ }^{238} \mathrm{Pu},{ }^{239} \mathrm{Pu}$ and ${ }^{90} \mathrm{Sr}$ in their tissues (Miramand et al. 1991; Nonnis Marzano et al. 2000; Bustamante et al. 2002). As for some metals (Brooks and Rumsby 1965, Chouvelon et al. 2009, Bustamante and Miramand 2004), scallops sometimes display higher bioaccumulation capacity for ${ }^{137} \mathrm{Cs}$ than other filter-feeders such as oysters and mussels occurring in the same areas (JCAC 
2002). Within the Pectinid family, the current knowledge on concentrations of anthropogenic radionuclides is limited to field measurements (Bustamante et al. 2002, Nonnis Marzano et al. 2000; Miramand and Germain 1986), and to waterborne exposure experiment to Am (Miramand and Germain 1986, Miramand et al. 1991). The importance of other contamination pathways in the bioaccumulation process of Am and $\mathrm{Cs}$ in scallops is not known although sediment and food have been considered as possible source of Am and Cs following the analyses carried out on scallops from the field or after laboratory studies (Miramand and Germain 1986, Nonnis Marzano et al. 2000) and by histo-autoradiography approach in laboratory (Miramand et al. 1991). Overall, sediment is considered as a major vector of transuranic elements, among which Am, to biota (Miramand et al. 1982, Bustamante et al. 2006, Ryan 2002). In comparison, Cs transfer from sediments appears relatively limited (Bustamante et al, 2006; Borretzen and Salbu, 2009). Recently, food has been demonstrated as a major pathway for metal bioaccumulation in scallops (Metian et al. 2009ab). Therefore, it appears necessary to determine experimentally the bioaccumulation of radionuclides in scallops via seawater, food and sediments in order to better understand the relative contribution of these three pathways of exposure.

The aim of this study was thus to determine the kinetics of uptake and depuration of ${ }^{241} \mathrm{Am}$ and ${ }^{134} \mathrm{Cs}$ in a typical pectinid from European waters, the king scallop Pecten maximus, following its exposure to radiolabelled seawater, food or sediment. The radionuclides were selected for their contrasting characteristics in seawater (particle-reactive Am and soluble Cs). There is a particular interest to study this transuranian and the radiocesium in $P$. maximus since the geographic distribution of this species (European North-Atlantic coasts) coincides with the area subject to direct inputs from the nuclear retreatment plants of Dounreay (Scotland - facility closed in 1996), La Hague (France) and Sellafield (England), which affect the Norway where Pecten maximus is cultured (Bergh and Strand, 2001). 


\section{$\underline{\text { 2. Materials and Methods }}$}

92

\subsection{Sampling}

In spring 2004 and 2005, seventy king scallops $P$. maximus were collected on the French Atlantic coast (Pertuis Breton, Charente-Maritime) by SCUBA diving. They were carefully transported to IAEA-MEL premises in Monaco and were acclimated to laboratory conditions for 4 weeks (constantly aerated, open-circuit 8001 aquarium; flux: $501 \mathrm{~h}^{-1}$; salinity: 36 p.s.u.; temperature: $17 \pm 0.5^{\circ} \mathrm{C} ; \mathrm{pH}: 8.0 \pm 0.1$; light/dark cycle: $12 \mathrm{~h} / 12 \mathrm{~h}$ ) prior to experimentations. During this period, scallops were fed daily an algal mixed diet (Isochrysis galbana, Skeletonema costatum).

\subsection{Radiotracer and counting}

Uptake and depuration kinetics of ${ }^{241} \mathrm{Am}$ and ${ }^{134} \mathrm{Cs}$ in scallop were determined using highspecific activity radiotracers purchased from Isotope Product Lab $\left({ }^{241}\right.$ Am nitrate $-0.1 \mathrm{~N}-, \mathrm{T}_{1 / 2}=$ 433 years; ${ }^{134} \mathrm{Cs}$ chloride $-0.1 \mathrm{~N}-, \mathrm{T}_{1 / 2}=2$ years $)$. Tracers were counted using a high-resolution $\gamma$-spectrometer system composed of four Germanium (N- or P-type) detectors (EGNC 33195-R, Canberra ${ }^{\circledR}$ and Eurysis ${ }^{\circledR}$ ) connected to a multi-channel analyzer and a computer equipped with a spectra analysis software (Interwinner $\left.{ }^{\circledR} 6\right)$. The radioactivity was determined by comparison with standards of known activity and of appropriate geometry. Measurements were corrected for counting efficiency and physical radioactive decay. The counting time was adjusted to obtain a propagated counting error less than 5\% (Rodriguez y Baena et al. 2006).

\subsection{Seawater exposure}

Twenty five $P$. maximus (average weight \pm SD: $208 \pm 46 \mathrm{~g}$ ) were placed in a $70-1$ glass aquarium (constantly aerated, closed-circuit aquarium; salinity: 36 p.s.u.; temperature: $17 \pm$ $0.5^{\circ} \mathrm{C} ; \mathrm{pH}: 8.0 \pm 0.1$; light/dark cycle: $12 \mathrm{~h} / 12 \mathrm{~h}$ ) and simultaneously exposed for $7 \mathrm{~d}$ to ${ }^{241} \mathrm{Am}$ and to ${ }^{134} \mathrm{Cs}$ dissolved in $0.45 \mu \mathrm{m}$ filtrated seawater $\left(0.3\right.$ and $1.4 \mathrm{kBq} 1^{-1}$, respectively). No change in $\mathrm{pH}$ was detectable after the tracer addition. Spiked seawater was renewed twice a 
116 day during the first two days and then daily in order to keep radioactivity in seawater

117 constant. Activity of the ${ }^{241} \mathrm{Am}$ and ${ }^{134} \mathrm{Cs}$ in seawater was checked before and after each spike 118 renewal, yielding time-integrated activities of $0.13 \pm 0.09 \mathrm{kBq}^{-1}$ and $1.23 \pm 0.03 \mathrm{kBq}^{-1}$ (

119 Nine tag-identified scallops were collected at different time intervals and were whole-body

120 radioanalyzed alive (same identified individual each time). At the end of the $7 \mathrm{~d}$ exposure

121 period, 5 scallops among the 25 were sacrificed and dissected. Shell, digestive gland, kidneys,

122 gills, gonad, mantle, intestine, adductor muscle and the remaining soft tissues were separated

123 and radioanalyzed in order to assess the radionuclide body distribution. The remaining

124 scallops were then placed in non contaminating conditions (constantly aerated, open-circuit 125 aquarium; flux: $501 \mathrm{~h}^{-1}$; salinity: 36 p.s.u.; temperature: $17 \pm 0.5{ }^{\circ} \mathrm{C} ; \mathrm{pH}$ : $8.0 \pm 0.1$; light/dark 126 cycle: $12 \mathrm{~h} / 12 \mathrm{~h}$ ) for $36 \mathrm{~d}$ and the nine tag-identified individuals were regularly radioanalyzed 127 alive in order to follow the depuration of ${ }^{241} \mathrm{Am}$ and ${ }^{134} \mathrm{Cs}$ from the scallops. Three non128 exposed individuals were introduced in the aquarium in order to control possible tracer 129 recycling from the contaminated scallops. During the $36 \mathrm{~d}$ depuration period, scallops were 130 fed daily with Skeletonema costatum and Isochrisis galbana $\left(5.10^{4}\right.$ cells $\left.\mathrm{ml}^{-1}\right)$. At the end of 131 the depuration period, four contaminated scallops were collected and dissected into several 132 body compartments as previously described.

\section{2.4. Food exposure}

134 The Bacillariophyceae Skeletonema costatum was used to study the transfer of ${ }^{241} \mathrm{Am}$ and

$135{ }^{134} \mathrm{Cs}$ to scallops through their diet. Phytoplankton cells were exposed to $4.5 \mathrm{kBq}{ }^{241} \mathrm{Am} 1^{-1}$ 136 and $7 \mathrm{kBq}{ }^{134} \mathrm{Cs}^{-1}$ during their exponential growing phase (10d). After that period, 137 phytoplankton medium was filtrated (1 $\mu$ m-mesh size; Osmonic filters), and the 138 phytoplankton cells resuspended in a 70-1 aquarium (constantly aerated, closed-circuit 139 aquarium; salinity: 36 p.s.u.; temperature: $17 \pm 0.5^{\circ} \mathrm{C} ; \mathrm{pH}: 8.0 \pm 0.1$; light/dark cycle: $12 \mathrm{~h} / 12$ $140 \mathrm{~h})$ at a cell concentration of $510^{4}$ cell $\mathrm{ml}^{-1}$ to avoid pseudofeces production by the scallops. 
141 Nine P. maximus (average weight \pm SD: $199 \pm 32 \mathrm{~g}$ ) had been placed in the aquarium for one

142 week before the feeding experiment. Scallops were then allowed to feed on radiolabelled $S$.

143 costatum for $2 \mathrm{~h}$. After the feeding period, all scallops were $\gamma$-counted and flowing seawater

144 conditions $\left(50 \mathrm{l} \mathrm{h}^{-1}\right)$ were restored in the aquarium. Individuals were then whole-body $\gamma$ -

145 counted alive at different time intervals to follow the depuration kinetics of both elements.

146 Three non-exposed individuals were introduced in the aquarium in order to control possible

147 tracer recycling from the contaminated scallops. During the $21 \mathrm{~d}$ depuration period, scallops 148 were fed daily with Skeletonema costatum and Isochrisis galbana $\left(5.10^{4}\right.$ cells $\left.\mathrm{ml}^{-1}\right)$. Four

149 contaminated individuals were randomly collected after $21 \mathrm{~d}$ and dissected to determine the

150 radionuclide distribution among the different body compartments (shell, digestive gland,

151 kidneys, gills, gonad, mantle, intestine, adductor muscle and the remaining soft tissues).

152 Radiolabelled S. costatum did not allow contaminating significantly the scallops with ${ }^{134}$ Cs.

153 Therefore, another phytoplankton species was used to study the trophic transfer of this

154 radionuclide. To this end, the Haptophyceae Isochrisis galbana was used following the same

155 method as previously described for S. costatum except that phytoplankton cells were exposed

156 to ${ }^{134} \mathrm{Cs}$ during $7 \mathrm{~d}$ (growing phase of I. galbana). Six P. maximus (average weight \pm SD: 127

$157 \pm 14 \mathrm{~g}$ ) were exposed and whole-body $\gamma$-counted alive at different time of the depuration 158 experiment (16d). Four individuals were dissected at the end of the depuration period to

159 determine the ${ }^{134} \mathrm{Cs}$ distribution among the different body compartments (same as described 160 above).

$161 \quad 2.5$. Sediment exposure

162 Since $P$. maximus lives buried into the sediment, ${ }^{241} \mathrm{Am}$ and ${ }^{134} \mathrm{Cs}$ exposure through sediment 163 was assayed. Sediment was collected in Wimereux (North-Atlantic coast of France).

164 Sediment grain size distribution was measured on a Mastersizer micro and the evaluation of 165 the dry/wet weight ratio was calculated after freeze drying in a LABCONCO Freezone18. 
166 Aerated sediment $(9 \mathrm{~kg})$ was placed in a plastic container, spiked with ${ }^{241} \mathrm{Am}(8 \mathrm{kBq})$ and

$167{ }^{134} \mathrm{Cs}(13 \mathrm{kBq})$ for $6 \mathrm{~d}$ with constant agitation, then used to form a homogeneous sediment 168 layer of $4 \mathrm{~cm}$ height in a 20-1 aquarium. Weakly bound radioisotopes were allowed to leach 169 overnight under flowing seawater $\left(50 \mathrm{l} \mathrm{h}^{-1}\right)$. Ten $P$. maximus (average weight $\pm \mathrm{SD}$ : $118 \pm 5$ $170 \mathrm{~g}$ ) were then placed for $13 \mathrm{~d}$ in the aquarium (open circuit; parameters as previously 171 described), and six tag-identified individuals were regularly whole-body radioanalyzed alive.

172 Sediment samples were also regularly collected and $\gamma$-counted to verify that the radiotracer 173 activities in sediment remained constant. Activity of ${ }^{241} \mathrm{Am}$ and ${ }^{134} \mathrm{Cs}$ in sediment was 174 constant all along the exposure period $\left(8.2 \pm 0.8\right.$ and $13.1 \pm 3.0 \mathrm{~Bq} \mathrm{~g}^{-1}$ wet wt, respectively). 175 At the end of the exposure period, four scallops were collected, dissected (shell, digestive 176 gland, kidneys, gills, gonad, mantle, intestine, adductor muscle and the remaining soft 177 tissues), weighed and radioanalyzed to determine the radionuclide body distribution. The 178 remaining six scallops were placed in non-contaminating depuration conditions for 31d (new 179201 glass aquarium with clean sediment under flowing seawater, $501 \mathrm{~h}^{-1}$, daily feeding on

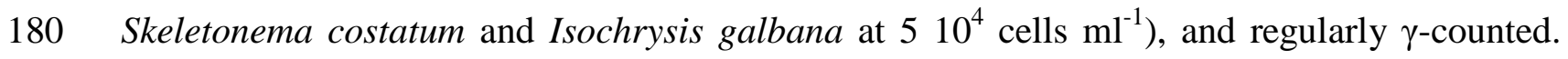

181 The radioactivity in sediment was regularly checked in order to ensure that no tracer recycling 182 occurred in the sediment. Although no radioactivity was detected, the whole sediment was 183 renewed after 1 week. After $31 \mathrm{~d}$ of depuration, four scallops were collected and dissected as 184 described above to determine body distribution of ${ }^{241} \mathrm{Am}$ and ${ }^{134} \mathrm{Cs}$.

\section{$185 \quad$ 2.6. Data analysis}

186 Uptake of the radioisotope was expressed in term of concentration factors (CF: ratio between 187 the radioisotope activity in scallops $-\mathrm{Bq} \mathrm{g}^{-1}$ wet wt- and time integrated activity in the 188 seawater $-\mathrm{Bq} \mathrm{g}^{-1}$-) over time for the seawater exposure and in term of transfer factors (TF: 189 ratio between the radioisotopes activity in scallops $-\mathrm{Bq} \mathrm{g}^{-1}$ wet wt- and time-integrated 190 activity in the sediment $-\mathrm{Bq} \mathrm{g}^{-1}$ wet wt-) over time for the sediment exposure of $P$. maximus. 
191 Uptake kinetics of ${ }^{241} \mathrm{Am}$ and ${ }^{134} \mathrm{Cs}$ in whole-body scallops were fitted (Statistica ${ }^{\circledR}$ 6) using a

192 simple exponential kinetic model (Eq. (1)) or using a linear model (Eq. (2)):

$193 \quad \mathrm{CF}_{\mathrm{t}}=\mathrm{CF}_{\mathrm{ss}}\left(1-\mathrm{e}^{-\mathrm{k}_{\mathrm{e}}^{\mathrm{t}}}\right)($ Eq. 1)

$194 \quad \mathrm{CF}_{\mathrm{t}}=\mathrm{k}_{\mathrm{u}} \mathrm{t}($ Eq. 2)

195 where $\mathrm{CF}_{\mathrm{t}}$ and $\mathrm{CF}_{\mathrm{ss}}\left(\mathrm{CF}_{\mathrm{ss}}=\mathrm{k}_{\mathrm{u}} / \mathrm{k}_{\mathrm{e}}\right)$ are the concentration factors at time $\mathrm{t}(\mathrm{d})$ and at steady state,

196 respectively; $\mathrm{k}_{\mathrm{u}}$ and $\mathrm{k}_{\mathrm{e}}$ are the uptake and depuration rate constants $\left(\mathrm{d}^{-1}\right)$, respectively

197 (Whicker and Schultz, 1982).

198 Depuration of ${ }^{241} \mathrm{Am}$ and ${ }^{134} \mathrm{Cs}$ (seawater, food and sediment experiments) was expressed in 199 terms of percentage of remaining radioactivity (radioactivity at time $t$ divided by initial 200 radioactivity measured in scallops at the beginning of the decontamination period*100). The 201 percentages of remaining activity were plotted against time and depuration kinetics were 202 described by a double-component exponential model (Eq. (3)):

$203 \quad A_{t}=A_{0 s} e^{-k_{e s} t}+A_{01} e^{-k_{e l} t}($ Eq. 3)

204 where $A_{t}$ and $A_{0}$ are the remaining activities (\%) at time $t(d)$ and 0 , respectively; $k_{e}$ is the 205 depuration rate constant $\left(\mathrm{d}^{-1}\right)$; 's' and ' $\mathrm{l}$ ' are the subscripts for the short-lived' and 'long-lived' 206 components. For each exponential component (s and 1), a biological half-life can be calculated $207\left(\mathrm{~T}_{\mathrm{b}^{1 / 2 \mathrm{~s}}}\right.$ and $\left.\mathrm{T}_{\mathrm{b}^{1 / 2}}\right)$ from the corresponding depuration rate constant ( $\mathrm{k}_{\mathrm{es}}$ and $\mathrm{k}_{\mathrm{el}}$, respectively) 208 according to the relation $\mathrm{T}_{\mathrm{b}^{1 / 2}}=\ln 2 / \mathrm{k}_{\mathrm{e}}$ (Warnau et al. 1996). Regarding feeding experiments, 209 the 'long-lived' exponential term describes the fraction of the radiotracer ingested with food 210 that is actually absorbed by the organism (Warnau et al. 1996). The corresponding $A_{01}$ 211 represents the assimilation efficiency (AE) of the considered radiotracer. The best fitting 212 regression models were selected according to highest determination coefficient and 213 examination of residuals. The level of significance for statistical analysis was always set at $\alpha$ $214=0.05$. 


\section{Results}

217 No mortality of scallops was recorded neither during acclimatation period nor during the 218 different experiments.

\subsection{Seawater exposure}

220 Uptake of ${ }^{241} \mathrm{Am}$ in whole-body P. maximus displayed linear kinetics $\left(\mathrm{R}^{2}=0.80\right.$; Fig. 1A, 1B 221 and Table 1) whereas the uptake of ${ }^{134} \mathrm{Cs}$ displayed exponential kinetics reaching a steady 222 state $\left(R^{2}=0.79\right)$. The values estimated for the kinetic parameters and their associated statistics are shown in Table 1. The concentration factors measured at the end of the exposure period $\left(\mathrm{CF}_{7 \mathrm{~d}}\right)$ of ${ }^{241} \mathrm{Am}$ and ${ }^{134} \mathrm{Cs}$ were $63 \pm 18$ and $1.0 \pm 0.2$ in whole body scallops, respectively. In the case of ${ }^{134} \mathrm{Cs}$, the estimated steady-state $\mathrm{CF}$ calculated by the model $226\left(\mathrm{CF}_{\mathrm{SS}}\right)$ reached $0.94 \pm 0.05$ (Fig. 1B and Table 1).

227 Calculated $\mathrm{CF}_{7 \mathrm{~d}}$ for the different compartments and organs are shown in Table 2. ${ }^{241} \mathrm{Am}$ is systematically more concentrated than ${ }^{134} \mathrm{Cs}$ when considering the same compartment of the scallops (up to 2 orders of magnitude). The shells of the scallops displayed higher capacities

230 of ${ }^{241} \mathrm{Am}$ bioconcentration than their whole soft parts (CFs: 130 vs. 30) whereas the opposite 231 was observed for ${ }^{134} \mathrm{Cs}$ (CFs: 1 vs. 3). Among the soft tissues, the digestive gland and the 232 kidneys presented the highest $\mathrm{CF}$ of ${ }^{241} \mathrm{Am}$ and ${ }^{134} \mathrm{Cs}$, respectively (Table 2).

233 At the end of the uptake experiment, the highest ${ }^{241} \mathrm{Am}$ load was in the shell (more than $90 \%$ 234 of the total body load) and that of ${ }^{134} \mathrm{Cs}$ was in whole soft parts (more than $70 \%$ of the total 235 load; Table 2). Among soft tissues, ${ }^{241} \mathrm{Am}$ was mainly contained in the mantle, digestive 236 gland and gills (34, 23 and $18 \%$ of total body load, respectively; Table 2) whereas ${ }^{134} \mathrm{Cs}$ was 237 mainly present in the adductor muscle and the mantle (41 and $24 \%$ of total body load, 238 respectively; Table 2).

239 When non-contaminating conditions were restored, the whole-body depuration kinetics of 240 both ${ }^{241} \mathrm{Am}$ and ${ }^{134} \mathrm{Cs}$ were best described by a two-component exponential model (Fig. 1C 
241 and Table 1). The major part of the bioaccumulated ${ }^{241} \mathrm{Am}$ was efficiently absorbed $\left(\mathrm{A}_{01}\right.$ : $24278 \%$ ) whereas only $45 \%$ of the bioaccumulated ${ }^{134} \mathrm{Cs}$ was absorbed in $P$. maximus. The 243 estimated depuration rate constant of the long-lived components $\left(\mathrm{k}_{\mathrm{el}}\right)$ for ${ }^{134} \mathrm{Cs}$ was $0.031 \pm$ $2440.004 \mathrm{~d}^{-1}$ and, consequently, the derived biological half-life reached $22 \pm 3 \mathrm{~d}$ (Table 1 ). In the 245 case of ${ }^{241} \mathrm{Am}$, the depuration rate constant was not significantly different from $0(\mathrm{p}<0.05)$, 246 thus the corresponding $\mathrm{T}_{\mathrm{b}^{1 / 2 l}}$ may thus be considered as infinite. However, an estimation of $\mathrm{T}_{\mathrm{b}^{1 / 2}}$ 247 based on the mean value of $\mathrm{k}_{\mathrm{el}}$ is shown in Table 1 (892d).

248 After 36d of depuration, the distribution of both radionuclides between the shell and the 249 whole soft parts remained similar to the one observed at the end of the exposure period: $250{ }^{241}$ Am was mainly found in the shell and ${ }^{134} \mathrm{Cs}$ in the soft tissues (Table 2). Within soft 251 tissues, radionuclide distribution displayed a different pattern than the one observed at the end 252 of the exposure period (Table 2). Indeed, the digestive gland contained the major part of total $253{ }^{241} \mathrm{Am}$ load (43\%) while the adductor muscle was the main storing organ for ${ }^{134} \mathrm{Cs}(76 \%)$.

254 Nevertheless, the activities of both radionuclides in all the compartments of $P$. maximus 255 decreased along the depuration phase (data not shown).

\section{3.2. Dietary exposure}

257 The depuration kinetics of the radionuclides ingested with food in whole body $P$. maximus 258 were best fitted by a double exponential model (Fig. 2A and Table 1). ${ }^{241} \mathrm{Am}$ and ${ }^{134} \mathrm{Cs}$ 259 displayed similar assimilation efficiencies $(20 \%<\mathrm{AE}<30 \%)$ and close depuration rate 260 constants, $\mathrm{k}_{\mathrm{el}}$, respectively $0.08 \pm 0.02$ and $0.05 \pm 0.02$, which give close $\mathrm{T}_{\mathrm{b}^{1 / 2 l}}(9 \pm 2 \mathrm{~d}$ and $14 \pm$ $2617 \mathrm{~d}$, respectively). At the end of the depuration period, ${ }^{241}$ Am load was essentially in the shell 262 (88\% of the total body load) whereas most of the Cs was associated to the soft tissues; Table 263 2). Among the soft tissues, the digestive gland contained the main part of ${ }^{241} \mathrm{Am}(46 \%)$ 264 whereas ${ }^{134} \mathrm{Cs}$ was mainly distributed between the digestive gland, the kidney, the mantle, the 
adductor muscle and the remaining tissues, with the digestive gland presenting the higher 266 average load, i.e., 27\% (Table 2).

\subsection{Sediment exposure}

268 Bioaccumulation of sediment-bound radionuclides was measured in P. maximus. However, 269 their whole-body uptake kinetics could not be fitted by a model having a biological meaning 270 (Fig. 2B and Table 3). At the end of the exposure period, the highest transfer factor (TF) 271 measured in for whole scallops was $0.011 \pm 0.003$ for ${ }^{241} \mathrm{Am}$ and $0.005 \pm 0.002$ for ${ }^{134} \mathrm{Cs}$. 272 Overall, the different body compartments displayed low $\mathrm{TF}_{13 \mathrm{~d}}$ with elevated standard deviations (Table 3). Consequently, none of the tissues could be identified as the main bioaccumulation organ using TF. However, in terms of body distribution, the shell displayed the main part of both radionuclides (> 75\%). Among soft tissues, the digestive gland and the adductor muscle contained the major part of ${ }^{241} \mathrm{Am}(47 \pm 17 \%)$ and ${ }^{134} \mathrm{Cs}(41 \pm 13 \%)$, respectively (Table 3).

The whole-body depuration kinetics of both ${ }^{241} \mathrm{Am}$ and ${ }^{134} \mathrm{Cs}$ after exposure to spiked sediment were best described by a two-compartment exponential equation (Fig. 2C and Table

1). The results indicated that $78 \%$ of ${ }^{241} \mathrm{Am}$ and $68 \%$ of ${ }^{134} \mathrm{Cs}$ previously bioaccumulated were 281 efficiently retained, with biological half-lives of $79 \pm 42 \mathrm{~d}$ and $74 \pm 49 \mathrm{~d}$, respectively. At the end of the 31d depuration period, both radionuclides were mainly associated to the shell (Table 3). The distribution of ${ }^{241} \mathrm{Am}$ showed that in soft tissues, the major part of the radionuclide was retained in the digestive gland with $49 \pm 7 \%$ of the total ${ }^{241} \mathrm{Am}$ load.

\section{$\underline{\text { 4. Discussion }}$}

287 Biomonitoring programs using scallops (Class Bivalvia, family Pectinidae) already exist 288 (Fegan et al. 2010, JCAC 2002). Interestingly, scallops show a high accumulation capacity for radionuclides (Miramand et al. 1991, Nonnis Marzano et al. 2000, Bustamante et al. 2002) 
that can be accumulated to higher degrees than in other bivalve species such as mussels 291 (JCAC 2002). However, little is known about the behavior of radionuclides in scallops and their mode of uptake in comparison to other bivalve families such as Ostreidae or Mytilidae (Ryan 2002). To the best of our knowledge, experimental investigations were limited to the

294 description of the uptake of waterborne ${ }^{241} \mathrm{Am}$ in $P$. maximus and to the localization of this transuranic element in the digestive gland cells (Miramand and Germain 1986, Miramand et al. 1991). Therefore, there is a lack of information on the uptake and retention of Am by scallops following other natural exposure pathways (i.e., food and sediment) although food and/or sediment were shown to constitute the main pathway of accumulation for $\mathrm{Ag}, \mathrm{Cd}, \mathrm{Co}$, $\mathrm{Pb}, \mathrm{Zn}$ (Metian et al. 2007, 2008b, 2009abc). Concerning Cs, no information on its bioaccumulation by scallops is currently available in the literature.

Using realistic activities of dissolved ${ }^{241} \mathrm{Am}$ (i.e., within the range of environmental levels), our study confirmed that ${ }^{241} \mathrm{Am}$ was efficiently accumulated in hard and soft tissues of the scallops, reaching a whole-body CF of 63 after $7 d$ of exposure. This $\mathrm{CF}$ value is relatively high for bivalves. For example, CF were 10-30 after 5d of exposure in Mytilus edulis (Bjeregaard et al. 1985), 230 after 28d of exposure in Cerastoderma edule and 140 after 31d of exposure in Scrobicularia plana (Miramand et al. 1987). This CF was higher than in other marine invertebrates such as the sea urchin Paracentrotus lividus for comparable exposure time (i.e., approx. 30; Warnau et al. 1996). For P. maximus, Miramand and Germain (1986) showed a CF of 80 but after a longer exposure period to radiolabelled seawater (i.e., 38d). Based on the linear model describing the uptake kinetics, the scallops from the present experiment should accumulate ${ }^{241} \mathrm{Am}$ up to a CF of 360 after $38 \mathrm{~d}$. This difference could be due to the size/weight difference of the studied organisms since the scallops of Miramand and Germain (1986) were half-lighter than our organisms. Indeed, previous works have shown 
314 that this factor affects metal bioaccumulation (Boyden 1974, 1977, Warnau et al. 1995,

315 Hédouin et al. 2007).

316 Following waterborne exposure, ${ }^{241} \mathrm{Am}$ was more efficiently concentrated than ${ }^{134} \mathrm{Cs}$ in

317 Pecten maximus ( 20 times higher, Table 1). This difference is often found when marine

318 organisms are exposed to these two radionuclides through seawater (Warnau et al. 1996;

319 Bustamante et al. 2006). It could be related to physico-chemicals properties of each

320 radionuclide: as a transuranic radionuclide, americium (III) is strongly particulate reactive

321 (Ryan 2002) while Cs is soluble and not reacting with particles. Such reactive properties of

322 Am would lead to direct adsorption onto shells. It is therefore not surprising that ca. 95\% of

323 the accumulated ${ }^{241} \mathrm{Am}$ was found on the shell of the scallops (Table 2). After they have been

324 accumulated from seawater, the radionuclides were depurated with very different rates with a

325 much shorter biological half-life for Cs (22d) than for Am (892d; Table 1). Such very long

326 biological half-life for Am might result from its retention on the shell. ${ }^{134} \mathrm{Cs}$ was mainly

327 present in the soft tissues, with $76 \%$ in the adductor muscle and the mantle (Table 2). This

328 specific accumulation pattern in muscular tissues is related to the analogous behavior of $\mathrm{Cs}^{+}$

329 for $\mathrm{K}^{+}$(Ke et al. 2000, Smith et al. 2002, Lacoue-Labarthe et al. 2010). The predominant

330 distribution of ${ }^{241} \mathrm{Am}$ in the calcitic skeleton/endoskeleton have been shown by several

331 authors (Grillo et al. 1981, Guary et al. 1982, Fowler and Carvalho 1985). Fowler and

332 Carvalho (1985) demonstrated a positive correlation between the ${ }^{241} \mathrm{Am} \mathrm{CF}$ in different

333 echinoderm species and the proportion of calcitic endoskeleton in the body wall of those

334 species. Recently, Zuykov et al. (2009) showed a preferential accumulation of ${ }^{241} \mathrm{Am}$ in the

335 organic periostracum of bivalve's shell. In $P$. maximus, it is noteworthy that the shell 336 contained most of ${ }^{241} \mathrm{Am}$ (up to $95 \%$ ) whatever the exposure pathway was (seawater, food or

337 sediment, Tables 2 and 3). According to our results of dietary exposure, it clearly appears

338 that, beside a direct adsorption of dissolved ${ }^{241} \mathrm{Am}$ on the shell, the radionuclide is also 
translocated from soft tissues (e.g. the digestive gland) to the shell. It is important to note that

340 the relative affinity of ${ }^{241}$ Am with the shell of $P$. maximus has been previously observed in the

341 field (Miramand and Germain 1986). A good perspective for the temporal record of ${ }^{241}$ Am in

342 shell would be the use of ICP-MS coupled to laser ablation that has been already used in

343 scallop for chronological survey of other elements (Thébault et al. 2009).

344 When scallops were fed radiolabelled phytoplankton, dietary ${ }^{241} \mathrm{Am}$ and ${ }^{134} \mathrm{Cs}$ were relatively 345 poorly assimilated (AE: 28 and 20\%, respectively; Table 1). Furthermore, both radionuclides 346 were rapidly depurated, resulting in relatively short biological half-lives (between 1 and 2 347 weeks). These AEs are much lower than in echinoderms and cephalopods for which they vary 348 from 33 to $90 \%$ and from 30 to $60 \%$, respectively (Ryan 2002, Bustamante et al. 2006). 349 However, our results for ${ }^{241} \mathrm{Am}$ are consistent with data reported for other bivalves, which 350 displayed low ${ }^{241} \mathrm{Am}$ assimilation. For example, AE of ${ }^{241} \mathrm{Am}$ ranged between 2 and $13 \%$ in mussels of the genus Mytilus (Baines et al. 2005). Such low AE by mussels could be related to the radionuclide association with mineral fractions of phytoplankton (e.g. diatom shells) or on algal cell surfaces (e.g., Chlorophyceae such as Dunaliella tertiolecta) due to the particle354 reactive properties of ${ }^{241} \mathrm{Am}$ (Fisher et al. 1983, Fisher and Teyssié 1986).

355 The scarcity of data on ${ }^{134} \mathrm{Cs}$ assimilation in marine invertebrates is conspicuous, especially 356 compared to ${ }^{241} \mathrm{Am}$ data on the subject. Nevertheless, ${ }^{134} \mathrm{Cs}$ is not well bioaccumulated by 357 phytoplankton. Heldal et al. (2001) working on ${ }^{134} \mathrm{Cs}$ uptake of five species (three 358 prymnesiophytes and two diatoms) have shown that phytoplankton is unlikely to influence the 359 Cs build-up in marine food webs and Cs flux to deep waters. Bivalves generally showed low 360 AE for Cs with values ranging between 0.4 and $10 \%$ in the green mussel Perna viridis (Wang et al. 2000). In predators, reported AEs for Cs are higher, ranging between 44 and $58 \%$ in the 362 gastropod Babylonia formosae habei and between 23 and $29 \%$ in the cuttlefish Sepia officinalis (Wang et al. 2000, Bustamante et al. 2006). 
365 Regarding their way of living and their nutrition, scallops are in direct contact with bottom sediments and predispose scallop to filter and ingest contaminated particles. For a species filtering large quantities of sediment particles, the TF obtained at the end of the exposure were quite low $\left(\mathrm{TF}_{13 \mathrm{~d}}\right.$ of ${ }^{241} \mathrm{Am}$ and ${ }^{134} \mathrm{Cs}<0.011$ with a maximum $\mathrm{TF}<0.05$ over the whole exposure period) but consistent with other sediment exposure studies (Miramand et al. 1982, Bustamante et al. 2006, Borretzen and Salbu 2009). In scallops from the field, radionuclide activity provides an integrated value of the bioaccumulation process. However, experimental approaches are compulsory to quantify the different physiological parameters of element bioaccumulation and to determine the relative 374 importance of the different exposure pathways (Warnau and Bustamante 2007). According to 375 the bioaccumulation kinetics of the radionuclides, Am seems to be mainly accumulated from the dissolved phase since exposure to particule-associated Am (food and sediment) resulted in 377 quite poor absorption and retention, compared to ${ }^{241} \mathrm{Am}$-dissolved bioaccumulation (efficient uptake and strong retention). In the case of the Cs, the kinetic analyses did not clearly 379 revealed a trend on the major uptake pathway, even though the low amount of Cs 380 bioaccumulated through sediment exposure (whole body $\mathrm{TF}<0.01)$ was highly absorbed $\left(\mathrm{A}_{01}\right.$ 381 of $68 \pm 7 \%)$ and strongly retained $\left(\mathrm{T}_{\mathrm{b}^{1 / 2}}=74 \mathrm{~d}\right)$. The use of a bioaccumulation model would 382 allow to further explore the importance of each exposure pathways sensu Thomann et al., 383 (1995) and their use have been already developed and applied on scallops in previous studies 384 (Metian et al. 2007, 2008b, 2009b). However, variability of the kinetic parameters obtained 385 during the sediment experiment was high because the exposure was relatively short. Thus the 386 bioaccumulation model with 3 exposure pathways could not be run in the present study. 387 Experiments with longer exposure periods will be necessary to better specify these 388 parameters. 


\section{$\underline{\text { 5. Conclusion }}$}

391 The present study provided new information about the different bioaccumulation pathways of

$392{ }^{241} \mathrm{Am}$ and ${ }^{134} \mathrm{Cs}$ that scallops are facing in the field. In this context, our data showed that the 393 shell and the adductor muscle appeared to be the best scallop compartments for monitoring 394 respectively ${ }^{241} \mathrm{Am}$ and ${ }^{134} \mathrm{Cs}$ in the marine environment.

Acknowledgments Authors are grateful to F. Oberhansli (IAEA-MEL) for skilful technical assistance and to M. Burlot (University of La Rochelle) for his help in scallop collection. MW is an Honorary Senior Research Associate of the National Fund for Scientific Research (NFSR, Belgium). This work was supported by the IAEA, the Conseil Général de la Charente-Maritime and the GIP Seine-Aval Programme. The IAEA is grateful for the support provided to its Marine Environment Laboratories by the Government of the Principality of Monaco. The experiments described herein comply with the current laws of the Principality of Monaco and France.

404

\section{References}

406 Baines, S.B., Fisher, N.S., Kinney, E.L., 2005. Influence of temperature on dietary metal 407 uptake in Arctic and temperate mussels. Mar. Ecol. Prog. Ser. 289, 201-213.

408 Bergh, Ø., Strand, Ø., 2001. Great scallop, Pecten maximus, research and culture strategies in 409 Norway: a review. Aquaculture Int. 9 (4), 305- 317.

410 Bjerregaard, P., Topçuoglu, S., Fisher, N.S., Fowler, S.W., 1985. Biokinetics of americium 411 and plutonium in the mussel Mytilus edulis. Mar. Ecol. Prog. Ser. 21, 99-111. 
412 Borretzen, P., Salbu, B., 2009. Bioavailability of sediment-associated and low-molecularmass species of radionuclides/trace metals to the mussel Mytilus edulis. J. Environ. Radioact. 100 (4), 333-341.

Boyden, C.R. 1974. Trace elements contents and body size in molluscs. Nature 251: 311-314.

Boyden, C.R. 1977. Effect of size upon metal content of shellfish. J. Mar. Biol. Ass. U.K. 57: $675-714$.

Brooks, R.R., Rumsby, M.G., 1965. The biogeochemistry of trace element uptake by some New Zealand bivalves. Limnol. Oceanogr. 10, 521-527.

Bryan, G.W. 1973. The occurence and seasonal variation of trace metals in the scallops Pecten maximus (L.) and Chlamys opercularis (L.). J. Mar. Biol. Ass. U.K. 53: 145-166.

Burger, J., Gochfeld, M., Jewett, S.C., 2007. Radionuclide levels in benthic invertebrates from Amchitka and Kiska Islands in the Aleutian Chain, Alaska. Environ. Monit. Assess. $123,371-391$.

Bustamante, P., Germain, P., Leclerc, G., Miramand, P., 2002. Concentration and distribution of ${ }^{210} \mathrm{Po}$ in the tissues of the scallop Chlamys varia and the mussel Mytilus edulis from the coasts of Charente-Maritime (France). Mar. Pollut. Bull. 44 (10), 997-1002.

Bustamante, P., Miramand, P., 2004. Interspecific and geographical variations of trace element concentrations in Pectinidae from European waters. Chemosphere 57, 1355-

Bustamante, P., Miramand, P., 2005. Subcellular and body distributions of 17 trace elements 1362.

Bustamante, P., Teyssié, J.-L., Fowler, S.W., Warnau, M., 2006. Assessment of the exposure pathway in the uptake and distribution of americium and cesium in cuttlefish (Sepia officinalis) at different stages of its life cycle. J. Exp. Mar. Biol. Ecol. 331 (2), 198-207. 
437 Chouvelon, T., Warnau, M., Churlaud, C., Bustamante, P., 2009. Hg concentrations and 438 related risk assessment in coral reef crustaceans, molluscs and fish from New Caledonia. $439 \quad$ Environ. Pollut. 157, 331-340.

440 Fegan, M., Currivan, L., Dowdall, A., Hanley, O., Hayden, E., Kelleher, K., Long, S., McKittrick, L., Somerville, S., Wong, J. Pollard, D., 2010. Radioactivity monitoring of the Irish environment 2008. RPII 01/10. Dublin: Radiological Protection Institute of Ireland.

Fisher, N.S., Teyssié, J.-L., 1986. Influence of food composition on the biokinetics and tissue distribution of zinc and americium in mussels. Mar. Ecol. Prog. Ser. 28, 197-207.

Fisher, N. S., Bjerregnard, P., Fowler, S. W., 1983. Interactions of marine plankton with transuranic elements. 1. Biokinetics of neptunium, plutonium, americium, and californium in phytoplankton. Limnol. Oceanogr. 28(3), 432-447.

Fowler, S.W., Carvalho, F.P., 1985. Americium biokinetics in benthic organisms as a function of feeding mode. Bull. Environ. Contam. Toxicol. 35, 826-834.

Friedlander, B.R., Gochfeld, M., Burger, J., Powers, C.W., 2005. Radionuclides in the marine Environment: a CRESP Science Review. Consortium for Risk Evaluation with Stakeholder Participation. Nashville, TN 95p.

Grillo, M.C., Guary, J.C., Fowler, S.W. 1981. Comparative studies on transuranium nuclide bio-kinetics in sediment-dwelling invertebrates (IAEA-SM-248/114). Vienna, IAEA, pp. 273-291.

Guary, J.-C., Fowler, S.W., Beasley, T.M., 1982. Routes of plutonium uptake and their relation to biomagnification in starfish. Mar. Pollut. Bull. 13(3), 99-102.

Hédouin, L., Metian, M., Cotret, O., Teyssié, J.-L., Fowler, S.W., Fichez, R., Warnau, M., 460 2006. Allometry of heavy metal bioconcentration in the edible tropical clam Gafrarium 461 tumidum. Sci. Total Environ. 366 (1), 154-163. 
462 Heldal, H.E., Stupakoff, I., Fisher, N.S., 2001. Bioaccumulation of ${ }^{137} \mathrm{Cs}$ and ${ }^{57}$ Co by five 463 marine phytoplankton species. J. Environ. Radioact. 57 (3), 231-236.

464 Japan Chemical Analysis Center (JCAC, 2002) Radioactivity survey data in Japan (part $2=$ 465 Dietary Materials). NIRS-RSD No 133. National Institute of Radiological Sciences, $466 \quad$ Chiba, Japan. 34 p.

467 Ke, C., Yu, K.N., Lam, P.K.S., Wang, W.X., 2000. Uptake and depuration of cesium in the 468 green mussel Perna viridis. Mar. Biol. 137, 567-575.

Lacoue-Labarthe, T., Warnau, M., Oberhänsli, F., Teyssié, J.-L., Bustamante, P., 2010. Contrasting accumulation biokinetics and distribution of ${ }^{241} \mathrm{Am}, \mathrm{Co}, \mathrm{Cs}, \mathrm{Mn}$ and $\mathrm{Zn}$ during the whole development time of the eggs of the common cuttlefish, Sepia officinalis. J. Exp. Mar. Biol. Ecol. 382 (2), 131-138.

Metian, M., Bustamante, P., Oberhänsli, F., Teyssié, J.-L., Warnau, M., 2007. Interspecific 474 comparison of $\mathrm{Cd}$ bioaccumulation in European Pectinidae (Chlamys varia and Pecten maximus). J. Exp. Mar. Biol. Ecol. 353 (1), 58-67.

Metian, M., Warnau, M., Cosson, R.P., Oberhänsli, F., Bustamante, P., 2008a. Bioaccumulation and detoxification processes of $\mathrm{Hg}$ in the king scallop Pecten maximus: field and laboratory investigations. Aquat. Toxicol. 90 (3), 204-213.

Metian, M., Bustamante, P., Cosson, R.P., Hédouin, L., Warnau, M., 2008b. Investigation of Ag in the king scallop Pecten maximus using field and laboratory approaches. J. Exp. Mar. Biol. Ecol. 367 (1), 53-60.

482 Metian, M., Bustamante, P., Hédouin, L., Oberhänsli, F., Warnau, M., 2009a. Delineation of 483 heavy metal uptake pathways (seawater and food) in the variegated scallop Chlamys varia using radiotracer techniques. Mar. Ecol. Prog. Ser. 375, 161-171. 
Metian, M., Warnau, M., Hédouin, L., Bustamante, P., 2009b. Bioaccumulation of essential metals ( $\mathrm{Co}, \mathrm{Mn}$ and $\mathrm{Zn})$ in the king scallop Pecten maximus: seawater, food and sediment exposures. Mar. Biol. 156 (10), 2063-2075.

Metian, M., Warnau, M., Oberhänsli, F., Bustamante, P., 2009c. Delineation of Pb contamination pathways in two Pectinidae: the variegated scallop Chlamys varia and the king scallop Pecten maximus. Sci. Total Environ. 407 (11), 3503-3509.

Miramand, P., Germain, P., Camus, N. 1982. Uptake of americium and plutonium from contaminated sédiments by three benthic species: Arenicola marina, Corophium volutator and Scrobicularia plana. Mar. Ecol. Prog. Ser. 7: 59-65.

Miramand, P., Germain, P., Arzur, JC. (1987) Uptake of curium $\left({ }^{244} \mathrm{Cm}\right)$ by five benthic marine species (Arenicola marina, Cerastoderma edule, Corophium olatator, Nereis diversicolor and Scrobicularia plana): comparison with americium and plutonium. J. Environ. Radioact. 5: 209-218.

Miramand, P., Germain, P., Boucaud-Camou, E., 1991. Histo-autoradiographic localization of americium in the tissues of the scallop Pecten maximus labelled from sea water: preliminary study on the transfer mechanisms. C. R. Acad. Sci. III, Sci. Vie 313, 395400.

Miramand, P., Germain, P., 1986. Experimental and in situ data (Goury, North Cotentin, France) on the concentration and distribution of Americium $\left({ }^{241} \mathrm{Am}\right)$ in the tissues of scallop Pecten maximus. Haliotis 15, 345-353.

Nielsen, K.S., Mattson, K.M., Kelly D.G., Bennett L.G.I., 2007. Environmental radionuclide monitoring programme. J. Radioanalyt Nuclear Chem. 271(3), 621-627.

Nonnis Marzano, F., Fiori, F., Jia, G., Chiantore, M., 2000. Anthropogenic radionuclides bioaccumulation in Antarctic marine fauna and its ecological relevance. Polar Biol. 23 (11), 753-758. 
Pan, K. and Wang, W.-X., 2008. Validation of biokinetic model of metals in the scallop Chlamys nobilis in complex field environments. Environ. Sci. Technol. 42, 6285-6290.

\section{2}

Rodriguez y Baena, A.M., Miquel, J.C., Masqué, P., Povinec, P., La Rosa, J. (2006b). A single vs. double spike approach to improve the accuracy of ${ }^{234} \mathrm{Th}$ measurements in small-volume seawater samples. Mar. Chem., 100, 269-281.

Ryan, T.P., 2002. Transuranic biokinetic parameters for marine invertebrates-a review. Environ. Internat. 28, 83-96.

Smith, J.T., Kudelsky, A.V., Ryabov, I.N., Daire, S.E., Boyer, L., Blust, R., Fernandez, J.A., Hadderingh, R.H., Voitsekhovitch, O.V., 2002. Uptake and elimination of radiocaesium in fish and the "size effect". J. Environ. Radioact. 62(2), 145-164.

Thébault, J., Chauvaud, L., L'Helguen, S., Clavier, J., Barats, A., Jacquet, S., Pecheyran, C., Amouroux, D., 2009. Barium and molybdenum records in bivalve shells: Geochemical proxies for phytoplankton dynamics in coastal environments? Limnol. Oceanogr. 54 (3), 1002-1014.

Thébault, H., Rodriguez Y Baena, A.M., Andral, B., Barisic, D., Benedicto Albaladejo, J., Bologa, A.S., Boudjenoun, R., Delfanti, R., Egorov, V., El Khoukhi T., Florou, H., Kmiewald, G., Noureddine, A., Patrascu, V., Pham, M.K., Scarpato, A., Stokozov, N., Topcuoglu, S., Warnau, M., 2008. ${ }^{137}$ Cs Baseline levels in the Mediterranean and Black Sea: a cross-basin survey of the CIESM Mediterranean Mussel Watch Programme. Mar. Pollut. Bull. 57, 801-806.

Thomann, R.V., Mahony, J.D., Mueller, R., 1995. Steady-state model of biota sediment accumulation factor for metals in two marine bivalves. Environ. Toxicol. Chem. 14, 19891998.

Toshimichi, I., Povinec P.P., Togawaa, O., Hirose K., 2003. Temporal and spatial variations of anthropogenic radionuclides in Japan Sea waters. Deep Sea Res. Part II 50(17-21), 

2701-2711.

536 Valette-Silver, N.J., Lauenstein, G.G., 1995. Radionuclide concentrations in bivalves 537 collected along the coastal United States. Mar. Pollut. Bull. 30, 320-331.

538 Wang, W.-X., Ke, C., Yu, K.N., Lam, P.K.S., 2000. Modeling radiocesium bioaccumulation 539 in a marine food chain. Mar. Ecol. Prog. Ser. 208, 41-50.

540 Warnau, M., Ledent, G., Temara, A., Alva, V., Jangoux, M., Dubois, P., 1995. Allometry of 541 heavy metal bioconcentration in the echinoid Paracentrotus lividus. Arch. Environ. $542 \quad$ Contam. Toxicol. 29(3), 393-399.

543 Warnau, M., Teyssié, J.-L., Fowler, S.W., 1996. Biokinetics of selected heavy metals and 544 radionuclides in the common Mediterranean echinoid Paracentrotus lividus: sea water and 545 food exposures. Mar. Ecol. Prog. Ser. 141, 83-94.

546 Warnau, M., Bustamante, P., 2007. Radiotracer Techniques: A unique tool in marine 547 ecotoxicological studies. Environ. Bioindicators 2, 217-218.

548 Whicker, F.W., Schultz, V., 1982. Radioecology: Nuclear Energy and the Environment. CRC $549 \quad$ Press, Boca Raton, FL. 320p.

550 Zuykov, M., Pelletier, E., Rouleau, C., Popov, L., Fowler, S.W., Orlova, M., 2009. Autoradiographic study on the distribution of ${ }^{241} \mathrm{Am}$ in the shell of the freshwater zebra mussel Dreissena polymorpha. Microchim. Acta 167, 173-178. 
Table 1. Whole-body uptake and depuration kinetic parameters of ${ }^{241} \mathrm{Am}$ and ${ }^{134} \mathrm{Cs}$ in Pecten maximus following different exposure experiments:

1) exposed for $7 d$ to waterborne radionuclides $(n=9)$ followed by $36 d$ of depuration $(n=9)$;

2) after a $2 \mathrm{~h}$ feeding on radiolabelled Skeletonema costatum for ${ }^{241} \mathrm{Am}$ followed by $21 \mathrm{~d}$ of depuration $(\mathrm{n}=9)$ and Isochrysis galbana for ${ }^{134} \mathrm{Cs}$ followed by $16 \mathrm{~d}$ of depuration $(\mathrm{n}=6)$

3) exposed for $13 d$ via the radiolabelled sediments $(n=6)$ and then maintained for $31 \mathrm{~d}$ in clean sediment and running seawater $(n=6)$

\begin{tabular}{|c|c|c|c|c|c|c|c|c|c|}
\hline \multirow[b]{2}{*}{ Experiment } & \multirow[b]{2}{*}{ Radionuclide } & \multicolumn{3}{|c|}{ Uptake } & \multicolumn{5}{|c|}{ Depuration } \\
\hline & & $\mathrm{CF}_{\mathrm{ss}} \pm \mathrm{ASE}$ & $\mathrm{k}_{\mathrm{u}} \pm \mathrm{ASE}$ & $\mathrm{R}^{2}$ & $\mathrm{~A}_{0 \mathrm{~s}} \pm \mathrm{ASE}$ & $\mathrm{T}_{\mathrm{b}^{1} / 2 \mathrm{~s}} \pm \mathrm{ASE}$ & $\mathrm{A}_{01} \pm \mathrm{ASE}$ & $\mathrm{T}_{\mathrm{b}^{1 / 2 l}} \pm \mathrm{ASE}$ & $\mathrm{R}^{2}$ \\
\hline \multirow[t]{2}{*}{ 1) Seawater } & ${ }^{2 \mathrm{~A} 1} \mathrm{Am}$ & - & $9.53 \pm 0.35^{\mathrm{d}}$ & 0.80 & $22.76 \pm 4.34^{\mathrm{d}}$ & $1.0 \pm 0.4^{\mathrm{a}}$ & $77.64 \pm 2.95^{\mathrm{d}}$ & 892 & 0.35 \\
\hline & ${ }^{134} \mathrm{Cs}$ & $0.94 \pm 0.05^{\mathrm{d}}$ & $0.55 \pm 0.07^{\mathrm{d}}$ & 0.79 & $54.87 \pm 3.88^{\mathrm{d}}$ & $0.5 \pm 0.1^{\mathrm{d}}$ & $45.02 \pm 2.92^{d}$ & $22 \pm 3^{d}$ & 0.89 \\
\hline \multirow[t]{2}{*}{ 2) Feeding } & ${ }^{2 \mathrm{~A} 1} \mathrm{Am}$ & - & - & - & $79.72 \pm 4.46^{\mathrm{d}}$ & $0.4 \pm 0.1^{\mathrm{d}}$ & $20.29 \pm 3.80^{\mathrm{d}}$ & $9 \pm 2^{c}$ & 0.93 \\
\hline & ${ }^{134} \mathrm{Cs}$ & - & - & - & $71.93 \pm 6.30^{\mathrm{d}}$ & 0.1 & $28.07 \pm 4.37^{\mathrm{d}}$ & $14 \pm 7^{\mathrm{a}}$ & 0.88 \\
\hline \multirow[t]{2}{*}{ 3) Sediment } & ${ }^{2 \mathrm{~A} 1} \mathrm{Am}$ & & n.a. & & $21.89 \pm 8.74^{\mathrm{a}}$ & 0.7 & $78.22 \pm 6.24^{\mathrm{d}}$ & $79 \pm 42$ & 0.35 \\
\hline & ${ }^{134} \mathrm{Cs}$ & & n.a. & & $32.01 \pm 11.63^{b}$ & 0.2 & $67.99 \pm 6.54^{d}$ & $74 \pm 49$ & 0.24 \\
\hline
\end{tabular}

Uptake parameters: $\mathrm{CF}_{\mathrm{ss}}$ : concentration factors at steady state; $\mathrm{k}_{\mathrm{u}}$ : uptake rate constant $\left(\mathrm{d}^{-1}\right)$.

Depuration parameters: $\mathrm{A}_{0 \mathrm{~s}}$ and $\mathrm{A}_{01}$ : remaining activity (\%) according to the short-and the long-lived exponential component, respectively; $\mathrm{T}_{\mathrm{b}^{1} / 2}$ : biological half-life (d). ASE: asymptotic standard error; $r^{2}$ : determination coefficient of the uptake or depuration kinetics.

Probability of the model adjustment: ${ }^{a} \mathrm{p}<0.05 .{ }^{\mathrm{b}} \mathrm{p}<0.01 .{ }^{\mathrm{c}} \mathrm{p}<0.001 .{ }^{\mathrm{d}} \mathrm{p}<0.0001$

n.a.: information not available. 
Table 2. Concentration Factors (mean $\mathrm{CF} \pm \mathrm{SD}$ ) and body distribution (mean $\% \pm \mathrm{SD}$ ) of ${ }^{241} \mathrm{Am}$ and ${ }^{134} \mathrm{Cs}$ in Pecten maximus during seawater (after $7 \mathrm{~d}$ of exposure and after $36 \mathrm{~d}$ of depuration) and feeding experiments (21d after feeding with Skeletonema costatum for ${ }^{241} \mathrm{Am}$ and $16 \mathrm{~d}$ after feeding with Isochrysis galbana for ${ }^{134} \mathrm{Cs}$ ).

\begin{tabular}{|c|c|c|c|c|}
\hline \multirow{3}{*}{$\begin{array}{l}\text { Radionuclides } \\
\text { Compartments }\end{array}$} & \multicolumn{3}{|c|}{ Seawater contamination } & \multirow{3}{*}{$\begin{array}{c}\text { Food contamination } \\
\text { Loss }(21 \text { or } 16 \mathrm{~d}, \mathrm{n}=4) \\
\text { Distribution } \\
(\%)\end{array}$} \\
\hline & \multicolumn{2}{|c|}{ Uptake $(7 \mathrm{~d}, \mathrm{n}=5)$} & \multirow{2}{*}{$\begin{array}{c}\text { Loss }(36 \mathrm{~d}, \mathrm{n}=4) \\
\text { Distribution } \\
(\%)\end{array}$} & \\
\hline & $\begin{array}{l}\text { Concentration } \\
\text { Factor }\end{array}$ & $\begin{array}{l}\text { Distribution } \\
(\%)\end{array}$ & & \\
\hline \multicolumn{5}{|l|}{${ }^{241} \mathrm{Am}$} \\
\hline Digestive gland & $140 \pm 51$ & $23 \pm 3$ & $43 \pm 6$ & $46 \pm 11$ \\
\hline Gills & $53 \pm 30$ & $18 \pm 3$ & $9 \pm 1$ & $7 \pm 2$ \\
\hline Kidneys & $40 \pm 14$ & $2 \pm 0$ & $3 \pm 1$ & $3 \pm 1$ \\
\hline Intestine & $109 \pm 75$ & $2 \pm 1$ & $<1$ & $5 \pm 4$ \\
\hline Gonad & $23 \pm 12$ & $5 \pm 2$ & $9 \pm 2$ & $4 \pm 2$ \\
\hline Foot & $44 \pm 23$ & $2 \pm 1$ & $<1$ & $2 \pm 2$ \\
\hline Mantle & $30 \pm 10$ & $34 \pm 2$ & $19 \pm 2$ & $27 \pm 7$ \\
\hline Adductor muscle & $8 \pm 3$ & $10 \pm 2$ & $7 \pm 3$ & $1 \pm 1$ \\
\hline Remaining tissues & $71 \pm 14$ & $6 \pm 4$ & $8 \pm 4$ & $2 \pm 2$ \\
\hline Whole soft part & $30 \pm 8$ & $7 \pm 3$ & $5 \pm 0$ & $12 \pm 7$ \\
\hline Shell & $130 \pm 21$ & $93 \pm 3$ & $95 \pm 0$ & $88 \pm 7$ \\
\hline \multicolumn{5}{|l|}{${ }^{134} \mathrm{Cs}$} \\
\hline Digestive gland & $6 \pm 2$ & $10 \pm 5$ & $14 \pm 2$ & $27 \pm 7$ \\
\hline Gills & $3 \pm 1$ & $11 \pm 7$ & $1 \pm 1$ & $4 \pm 2$ \\
\hline Kidneys & $8 \pm 1$ & $3 \pm 1$ & $2 \pm 0$ & $16 \pm 10$ \\
\hline Intestine & $2 \pm 0$ & $<1$ & $<1$ & $1 \pm 1$ \\
\hline Gonad & $3 \pm 0$ & $6 \pm 3$ & $1 \pm 0$ & $5 \pm 1$ \\
\hline Foot & $4 \pm 1$ & $2 \pm 0$ & $<1$ & $3 \pm 1$ \\
\hline Mantle & $2 \pm 0$ & $24 \pm 5$ & $5 \pm 0$ & $16 \pm 16$ \\
\hline Adductor muscle & $3 \pm 1$ & $41 \pm 13$ & $76 \pm 3$ & $14 \pm 10$ \\
\hline Remaining tissues & $4 \pm 0$ & $2 \pm 1$ & $<1$ & $11 \pm 11$ \\
\hline Whole soft part & $3 \pm 1$ & $76 \pm 6$ & $92 \pm 2$ & n.a. \\
\hline Shell & $<1$ & $24 \pm 6$ & $8 \pm 2$ & n.a. \\
\hline
\end{tabular}

n.a.: information not available. 
Table 3. Transfer Factors (mean TF \pm SD) of ${ }^{241} \mathrm{Am}$ and ${ }^{134} \mathrm{Cs}$ in Pecten maximus after $13 \mathrm{~d}$ of exposure via sediment and body distribution (mean $\% \pm \mathrm{SD}$ ) of ${ }^{241} \mathrm{Am}$ and ${ }^{134} \mathrm{Cs}$ at the end of the $13 d$ exposure $(n=4)$ and $31 d$ depuration periods $(n=4)$

\begin{tabular}{|c|c|c|c|}
\hline \multirow{3}{*}{$\begin{array}{l}\text { Radionuclides } \\
\text { Compartments }\end{array}$} & \multicolumn{3}{|c|}{ Sediment contamination } \\
\hline & \multicolumn{2}{|c|}{ Uptake $(13 \mathrm{~d}, \mathrm{n}=4)$} & \multirow{2}{*}{$\begin{array}{c}\text { Loss }(31 \mathrm{~d}, \mathrm{n}=4) \\
\text { Distribution } \\
(\%)\end{array}$} \\
\hline & $\begin{array}{l}\text { Transfer } \\
\text { Factor }\end{array}$ & $\begin{array}{c}\text { Distribution } \\
\quad(\%)\end{array}$ & \\
\hline \multicolumn{4}{|l|}{${ }^{241} \mathrm{Am}$} \\
\hline Digestive gland & $0.18 \pm 0.07$ & $47 \pm 17$ & $49 \pm 7$ \\
\hline Gills & $0.02 \pm 0.02$ & $10 \pm 10$ & $8 \pm 1$ \\
\hline Kidneys & $0.04 \pm 0.04$ & $3 \pm 3$ & $3 \pm 1$ \\
\hline Intestine & $0.08 \pm 0.07$ & $2 \pm 2$ & $9 \pm 9$ \\
\hline Gonad & $0.31 \pm 0.31$ & $14 \pm 14$ & $4 \pm 2$ \\
\hline Foot & $0.03 \pm 0.01$ & $2 \pm 1$ & $6 \pm 2$ \\
\hline Mantle & $<0.01$ & $14 \pm 9$ & $3 \pm 1$ \\
\hline Adductor muscle & $<0.01$ & $3 \pm 3$ & $16 \pm 2$ \\
\hline Remaining tissues & $0.04 \pm 0.02$ & $4 \pm 4$ & $1 \pm 1$ \\
\hline Whole soft part & $0.02 \pm 0.02$ & $19 \pm 11$ & $8 \pm 2$ \\
\hline Shell & $0.03 \pm 0.01$ & $81 \pm 11$ & $92 \pm 2$ \\
\hline \multicolumn{4}{|l|}{${ }^{134} \mathrm{Cs}$} \\
\hline Digestive gland & $0.02 \pm 0.02$ & $16 \pm 11$ & $19 \pm 13$ \\
\hline Gills & $<0.01$ & $11 \pm 5$ & $16 \pm 18$ \\
\hline Kidneys & $0.02 \pm 0.01$ & $3 \pm 1$ & $31 \pm 40$ \\
\hline Intestine & $0.06 \pm 0.06$ & $4 \pm 4$ & $3 \pm 3$ \\
\hline Gonad & $0.04 \pm 0.04$ & $12 \pm 6$ & $12 \pm 13$ \\
\hline Foot & $0.08 \pm 0.08$ & $10 \pm 10$ & $3 \pm 1$ \\
\hline Mantle & $<0.01$ & $18 \pm 8$ & $3 \pm 2$ \\
\hline Adductor muscle & $<0.01$ & $41 \pm 13$ & $11 \pm 11$ \\
\hline Remaining tissues & $0.02 \pm 0.02$ & $5 \pm 3$ & $2 \pm 1$ \\
\hline Whole soft part & $0.005 \pm 0.003$ & $25 \pm 1$ & $24 \pm 16$ \\
\hline Shell & $0.006 \pm 0.002$ & $75 \pm 1$ & $76 \pm 16$ \\
\hline
\end{tabular}




\section{Figures captions:}

Fig. 1. Uptake kinetics of (A) ${ }^{241} \mathrm{Am}$ and (B) ${ }^{134} \mathrm{Cs}$ in Pecten maximus exposed for $7 \mathrm{~d}$ to dissolved radiotracers $(n=9)$ and their following $36 \mathrm{~d}$ of depuration kinetics $(C)(n=9)$.

All values are mean \pm SD .

Fig. 2. Kinetics of ${ }^{241} \mathrm{Am}$ and ${ }^{134} \mathrm{Cs}$ in Pecten maximus (A) Depuration after a $2 \mathrm{~h}$ feeding on radiolabelled Skeletonema costatum for ${ }^{241} \mathrm{Am}$ followed by $21 \mathrm{~d}$ of depuration $(\mathrm{n}=9)$ and Isochrysis galbana for ${ }^{134} \mathrm{Cs}$ followed by $16 \mathrm{~d}$ of depuration $(\mathrm{n}=6)$; Uptake and depuration kinetics of ${ }^{241} \mathrm{Am}$ and ${ }^{134} \mathrm{Cs}$ in Pecten maximus (B) exposed for $13 \mathrm{~d}$ to the radiolabelled sediments $(n=6)$ and $(C)$ then maintained for $31 d$ in clean sediment and seawater $(n=6)$. All values are mean \pm SD. 

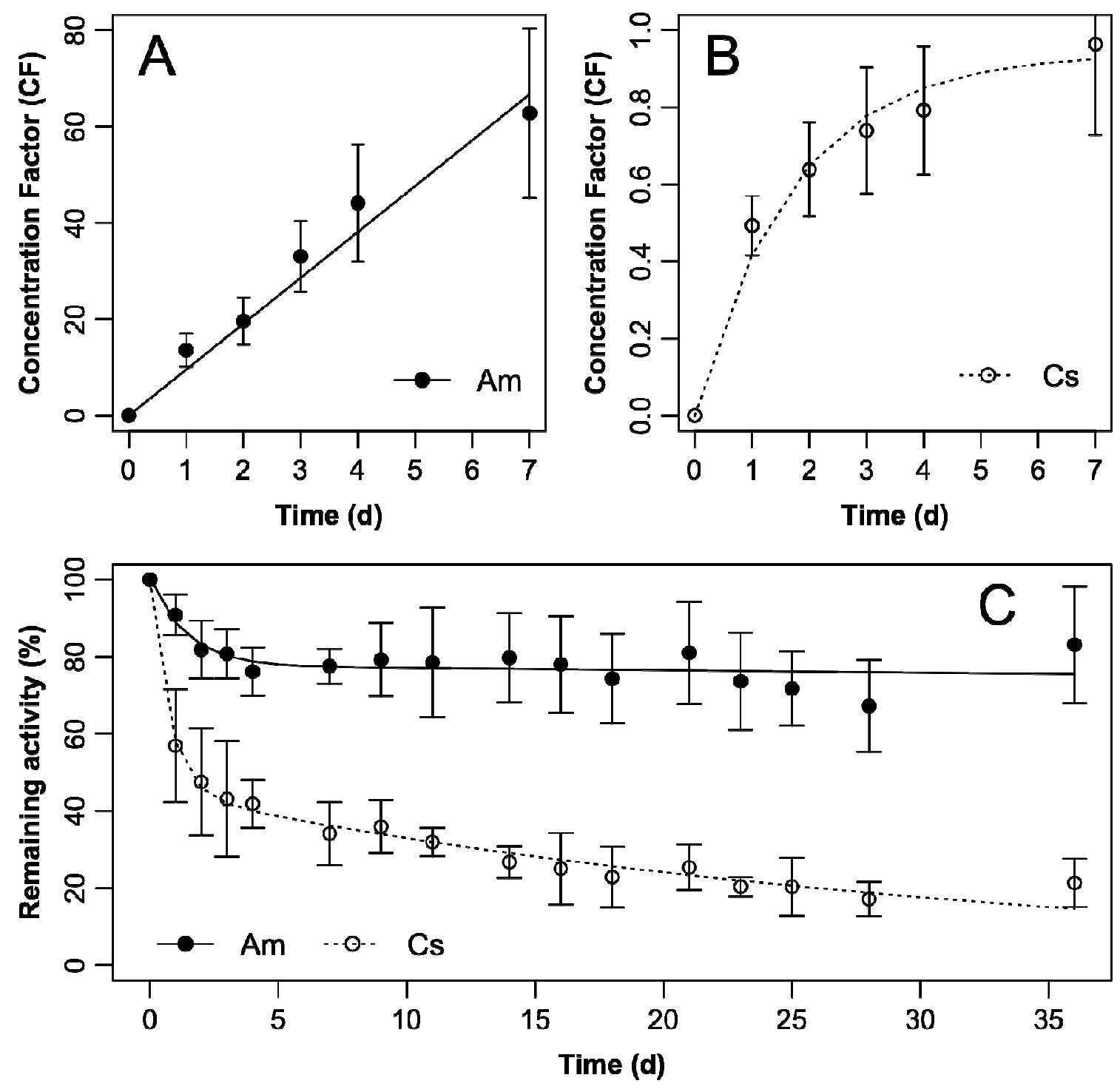

Figure 1 

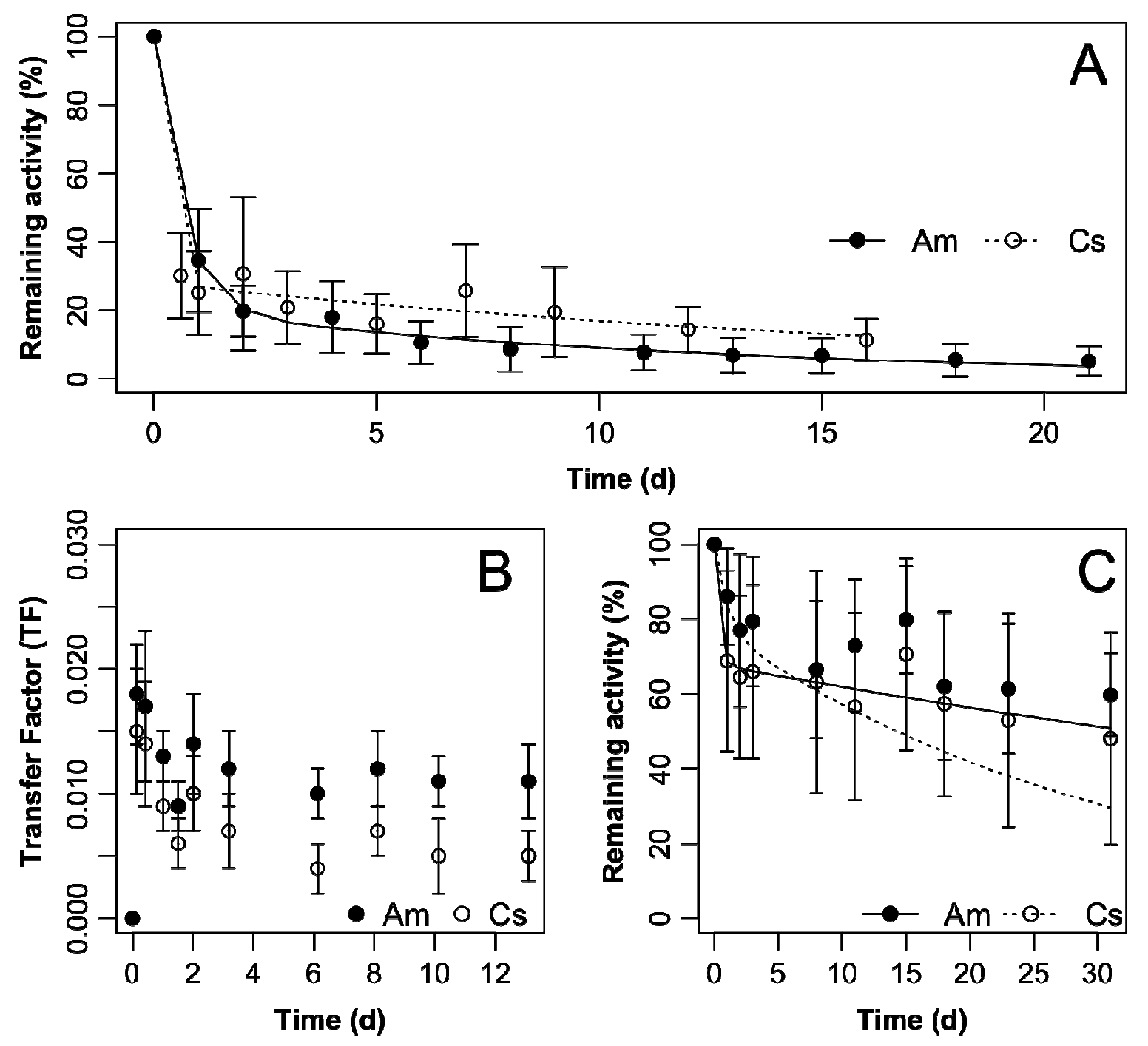

Figure 2 